\title{
Depositional patterns at Drift 7, Antarctic Peninsula: Along-slope versus down-slope sediment transport as indicators for oceanic currents and climatic conditions
}

\author{
Gabriele Uenzelmann-Neben \\ Alfred-Wegener-Institut für Polar- und Meeresforschung, Postfach 120161, 27515 Bremerhaven, Germany \\ Received 13 October 2005; received in revised form 15 August 2006; accepted 21 August 2006
}

\begin{abstract}
Understanding the processes and phases of deep-sea sediment drift formation is essential for a reconstruction of their evolution. This leads to a better understanding of the properties of oceanographic currents active during drift formation and in turn to information on the climatic conditions. A system of sediment drifts at the Antarctic Peninsula Pacific rise has been chosen to learn more about the Neogene evolution of both current systems and palaeo-climate in that area. Drift 7 was extensively surveyed (seismic and sampling), and two ODP Leg 178 sites were drilled there. Using this information, maps of reflectors depth and seismic unit thickness were compiled and interpreted regarding the controlling depositional processes. The depositional model shows an initially major along-slope sediment transport by a SW-setting bottom current (25-15 Ma), which deflected sediment supplied from the continental shelf. Between 15 Ma and 9.5 Ma down-slope transport took over as a result of the growth of the Antarctic Peninsula ice sheet. The SW setting bottom current appears to have broken down. Down-slope transport has decreased since 9.5 Ma, but a re-onset of the bottom current can only be observed since 5.3 Ma. The analysis has further shown that the nucleus of the drift is connected to a basement ridge. It is hence inferred that basement topography played a major role in the formation of this sediment drift.
\end{abstract}

(C) 2006 Elsevier B.V. All rights reserved.

Keywords: sediment drift; depositional patterns; thickness and reflector depth maps; depositional model; Drift 7; Antarctic Peninsula; ODP Leg 178 Sites 1095 and 1096

\section{Introduction}

Thermohaline-driven bottom currents (contour currents) and their related deposits, generally termed contourites, gained an increasing amount of attention during the last three decades. This is due to the fact that drift deposits contain a record of palaeoenvironmental information about ice sheet development and oceanography, and this archive is hence used to gain knowledge on

E-mail address: guenzelmann@awi-bremerhaven.de. the palaeoclimatic development of a certain region. "Drift" is a more general term compared to "contourite" and refers to larger sediment deposits with an often complex internal architecture, which are generated by persistent currents of thermohaline origin (Pickering et al., 1989). Publications of the last years concentrated on the recognition and classification of bottom-currentcontrolled deep-sea deposits in sediments and seismic data (Viana et al., 1998) and their interaction with turbidites (Faugères and Stow, 1993; Stow et al., 1998; Faugères et al., 1999; Stow et al., 2002). A recent 
publication by Shanmugam (2000) critically reviewed the facies models proposed for deep-water processes during the last 50 years. This discussion shows that the interplay between contour and turbidity currents is not yet fully understood (Faugères and Stow, 1993; Faugères et al., 1999). Nevertheless, it has become increasingly clear that both down-slope and along-slope processes play crucial and interactive roles in the construction and shaping of continental margins.

Transport, erosion and deposition of sedimentary particles are fundamental processes in the benthic boundary layer because they represent the link between oceanographic processes in the water column and the documentation of these processes in the sedimentary record. Harris et al. (2001) proposed that the sea ice regime and production of bottom water are closely related, and thus, the amount of deposited material in a sediment drift is connected to glacial-interglacial cycles. Sedimentary structures and textures hence constitute archives of the depositional and re-depositional environment and processes. By an inversion of those features into the generating process, the analysis of sedimentary structures can lead to a deciphering of the acting oceanographic conditions and, thus, to a better understanding of the development of both oceanographic currents and the climate in a particular area.

Variations in the volume and extent of Antarctica's ice sheets and sea ice cover in the Southern Ocean have a strong effect on Earth's climate via the planetary albedo, eustatic sea level, atmospheric and oceanic circulation. The puzzle of Antarctica's Neogene glacial history is still unsolved (e.g., Stroeven et al., 1998); many pieces, such as the question of major deglaciation during the warm Pliocene period, remain to be unravelled. In order to learn more about the Neogene history of bottom currents and the extension of Antarctica's ice sheet marine geophysical data sets of a sedimentary drift in the Pacific Sector of the continental margin of Antarctica were analysed.

A system of 12 sediment drifts west of the Antarctic Peninsula have been extensively surveyed (Rebesco et al., 1996, 1997; Camerlenghi et al., 1997; Lucchi et al., 2002; Giorgetti et al., 2003). About $4000 \mathrm{~km}$ of multichannel seismic reflection data (Rebesco et al., 1996) and three ODP Leg 178 site (Barker et al., 1999, 2002) allow a detailed investigation of the different sedimentary units. I will discuss the distribution of the seismic units of Drift 7, which was sampled at ODP Leg 178 Sites 1095 and 1096 and present a model for the interplay of down-slope and along-slope sediment transport. This in turn is interpreted with respect to the controlling oceanographic and climatic conditions.

\section{Geological and oceanographic background}

On the Pacific margin of the Antarctic Peninsula, a thick sequence of late Cenozoic to Holocene sediments records the history of bottom-water flow and West Antarctic glaciation (Tucholke et al., 1976). Of specific interest is a series of large mounds aligned along the continental rise between $63^{\circ}$ and $69^{\circ} \mathrm{S}$ (McGinnis and Hayes, 1995; Rebesco et al., 1998). Twelve sedimentary mounds have been identified, separated by large channels (Fig. 1). Their shape generally is asymmetric with steeper, rougher slopes to the southwest and southeast and gentle slopes to the northeast and northwest. The origin of these sediment bodies is discussed controversially: McGinnis and Hayes (1995) favoured a strong turbiditic (down-slope) influence during mound growth and point out distinct differences between each of the mounds, which indicate differences in sediment supply by turbidity and contouritic currents, whereas Rebesco et al. $(1996,1997,2002)$ proposed a strong importance of contour-current activity for the development of the mounds and interpreted them as drift bodies.

Evolutionary models of mound formation, based on grids of seismic profiles, basically consist of three major stages (McGinnis and Hayes, 1995; Rebesco et al., 1997). Those models will be outlined briefly in the following. The first, a pre-drift stage (pre-late Oligocene to Miocene according to McGinnis and Hayes, 1995; lasting from $\sim 35 \mathrm{Ma}$ until $15 \mathrm{Ma}$ according to Rebesco et al., 1997), is mainly characterized by turbiditic sequences, becoming more pelagic/hemipelagic with distance from the margin. The upper boundary of this stage is marked by a distinct reflector, which Rebesco et al. (1997) believed to represent an erosional event caused by the onset of the Antarctic Circumpolar Current (ACC) after the opening of the Drake Passage. The second, a drift-growth stage (lasting from $\sim 15 \mathrm{Ma}$ until 5 Ma, Rebesco et al., 1997), shows increasing evidence of bottom currents and drift development. During this stage, the mounds developed as sediment drift bodies by a combination of down-slope and alongslope processes. Large glacial sediment supply from the margin provides the material. The cause for the establishment of a strong bottom current regime is seen in the thermal isolation of the Antarctic continent after the opening of a deep Drake Passage. The timing for this is still controversially discussed. While Latimer and Filippelli (2002) suggest $32.8 \mathrm{Ma}$, Pfuhl and McCave (2005) argue for the opening of a deep Drake Passage near the Oligocene-Miocene boundary. Nevertheless, this led to a transition to dominantly glacial conditions with formation of bottom-water masses on the shelves 
and a build-up of large ice masses. Repeated grounded ice-sheet advances onto the shelf increased the sedimentation rates at the shelf edge significantly and caused a lively activity of small-volume slumps and debris flows on the uppermost continental slope (McGinnis and Hayes, 1995; Rebesco et al., 1997). McGinnis and Hayes (1995) proposed a progressively decreasing bottom current influence to the northeast for the second stage. The third, a drift-maintenance stage (lasting from $\sim 5$ Ma until recent, Rebesco et al., 1997), shows preservation and enhancement of the elevation of the drifts with clearly decreased bottom current speeds and sediment supplies (McGinnis and Hayes, 1995; Rebesco et al., 1997).

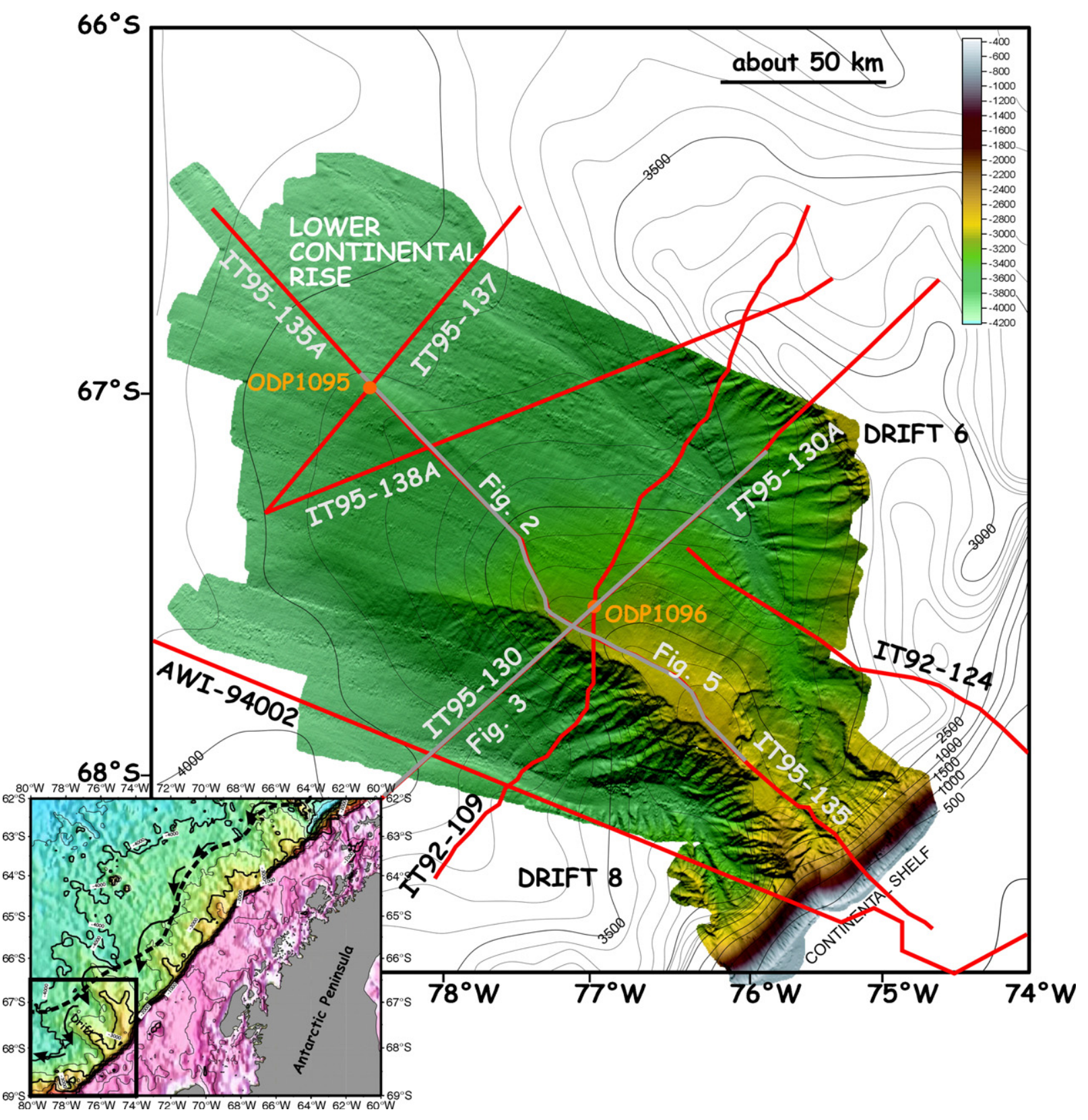

Fig. 1. Swath bathymetric map of Drift 7 (Rebesco et al., in press). The grey lines show the seismic sections displayed in Figs. 2 and 4 . The insert map shows the location of Drift 7 at the continental margin of the Antarctic Peninsula (black box, bathymetry according to Smith and Sandwell, 1997) of the southern ACC front (dashed line, according to Orsi et al., 1995) and the inferred southwest setting bottom current (thin arrows, according to Giorgetti et al., 2003). 
Two oceanographic fronts are located directly west of the Antarctic Peninsula, the Polar Front in the north and the southern boundary of the ACC in the south (Orsi et al., 1995). The water column in the Bellingshausen Sea consists of a thin surface layer of cold Antarctic Surface Water (AASW) and underlying warm, saline Circumpolar Deep Water (CDW), which locally protrudes onto the shelf (e.g., Hofmann et al., 1996). In the Pacific sector of the Southern Ocean, CDW represents a mixture of North Atlantic Deep Water (NADW) and recirculated waters from the Indian and Pacific Oceans (Patterson and Whitworth, 1990).

Surface water currents on the shelf west of the Antarctic Peninsula show weak cyclonic gyres (Smith et al., 1999). The circulation of deep and bottom water masses along the Antarctic Peninsula is still discussed controversially (Camerlenghi et al., 1997; Smith et al., 1999). Still, evidence has been put forward for the south-westward flow of deep and bottom-water masses, which originate in the Weddell Sea, as far as $63^{\circ} \mathrm{W}$ on the Antarctic Peninsula slope (Whitworth et al., 1998) and at least $78^{\circ} \mathrm{W}$ on the continental rise (Camerlenghi et al., 1997; Giorgetti et al., 2003). Mean bottom current speeds measured today in the area of Drift 7 are in the range of $6 \mathrm{~cm} \mathrm{~s}^{-1}$ (Camerlenghi et al., 1997).

\section{Seismic stratigraphy}

In general, I followed and applied the seismostratigraphic model as defined by Rebesco et al. (1997). Using the information supplied by ODP Leg 178 Sites 1095 and 1096 for Drift 7 (Shipboard Scientific Party, 1999a,b) and Site 1101 for Drift 4 (Shipboard Scientific Party, 1999c) the age model for the seismic units was refined. P-wave velocities supplied by Volpi et al. (2002) were used to convert the geological information from depth into two-way traveltime. Moreover, the ages for the older not drilled units were ascertained on the basis of correlation with DSDP Site 325 (Tucholke et al., 1976) and ages of the underlying crust (Larter et al., 1997).

The oldest unit M6 is interpreted by Rebesco et al. (1997) as a mainly turbiditic sequence deposited between $36 \mathrm{Ma}$ and $25 \mathrm{Ma}$ (Table 1). This age for the unit is based on DSDP Site 325, since it was not drilled by ODP Leg 178 (Figs. 2 and 3). The same applies to unit M5. Rebesco et al. (1997) describe unit M5 as a succession of planar reflectors gradually thinning oceanwards and rapidly thinning at the base of the slope. They interpret the unit as a mainly distal turbiditic succession deposited between $25 \mathrm{Ma}$ and $15 \mathrm{Ma}$.

Unit M4 varies substantially in thickness (Figs. 2 and 3). It was interpreted to mark the transition to a higher energy regime and marks the onset of drift buildup (Rebesco et al., 1997). While Rebesco et al. (1997) assume the unit's age to be 15-8 Ma, the results of ODP Leg 178 Site 1095 enable a revision (Table 1). Using the palaeomagnetic age model provided by Acton et al. (2002), which was supported by the biostratigraphic data of Iwai et al. (2002), the age of unit M4 is refined to be 15-9.5 Ma. According to Rebesco et al. (1997), unit M3 records the main phase of drift development. They correlate unit M3 with the onset of the development of the glacial margin sequences on the shelf and assume an age of $8-5 \mathrm{Ma}$ for the unit. This age was revised to 9.55.3 Ma applying the age-depth models of Acton et al. (2002) and Iwai et al. (2002) (Table 1).

Unit M2 is characterised by a uniform thickness of highamplitude, laterally continuous parallel reflectors. Rebesco et al. (1997) estimated this unit to have been deposited between $5 \mathrm{Ma}$ and $2.5 \mathrm{Ma}$. The revision here shows an age of 5.3-3 Ma. (Table 1). The reflection characteristics of unit M1 are quite similar to unit M2. Rebesco et al. (1997) consider this unit to comprise the period from $2.5 \mathrm{Ma}$ to today, which is here refined to $3 \mathrm{Ma}$ to present.

The revision of the sedimentary units' ages led to a re-examination of the sedimentation rates. To

Table 1

Compilation of sedimentary units, their ages, thickness and sedimentation rates according to Rebesco et al. (1997) and this revision

\begin{tabular}{|c|c|c|c|c|c|c|c|}
\hline $\begin{array}{l}\text { Sedimentary } \\
\text { unit }\end{array}$ & $\begin{array}{l}\text { Unit age } \\
\text { (Rebesco et al., } \\
\text { 1997) } \\
\text { (Ma) }\end{array}$ & $\begin{array}{l}\text { Unit age } \\
\text { (revised) } \\
(\mathrm{Ma})\end{array}$ & $\begin{array}{l}\text { Unit thickness } \\
\text { (Rebesco et al., 1997; } \\
\text { compacted) } \\
\text { (m) }\end{array}$ & $\begin{array}{l}\text { Unit } \\
\text { thickness } \\
(\mathrm{rms})(\mathrm{m})\end{array}$ & $\begin{array}{l}\text { Sedimentation rates } \\
\text { (Rebesco et al., 1997; } \\
\text { compacted) } \\
(\mathrm{m} / \mathrm{my})\end{array}$ & $\begin{array}{l}\text { Sedimentation } \\
\text { rates (revised) } \\
(\mathrm{m} / \mathrm{my})\end{array}$ & $\begin{array}{l}\text { Accumulation } \\
\text { rates } \\
\left(10^{11} \mathrm{~m}^{3} / \mathrm{my}\right)\end{array}$ \\
\hline M1 & $0.0-2.5$ & $0.0-3.0$ & 333 & 210 & 133.2 & 67.7 & 2.8 \\
\hline M2 & $2.5-5.0$ & $3.0-5.3$ & 314 & 188.9 & 125.6 & 82.1 & 3.05 \\
\hline M3 & $5.0-8.0$ & $5.3-9.5$ & 374 & 260.6 & 124.67 & 62 & 5.2 \\
\hline M4 & $8.0-15.0$ & $9.5-15.0$ & 400 & 310.3 & 57.14 & 56.4 & 8.36 \\
\hline M5 & $15.0-25.0$ & $15.0-25.0$ & 319 & 223.4 & 31.9 & 22 & 0.77 \\
\hline M6 & $25.0-36.0$ & $25.0-36.0$ & 795 & 526.5 & 72.27 & 48 & 1.31 \\
\hline
\end{tabular}

Rebesco et al. (1997) computed their sedimentation rates at a specific location under the gentle flank of Drift 7 on profile IT92-109, whereas I use the rms - values computed for the whole of each sedimentary unit. The accumulation rates are estimated in reference to the depocentre of each unit. 


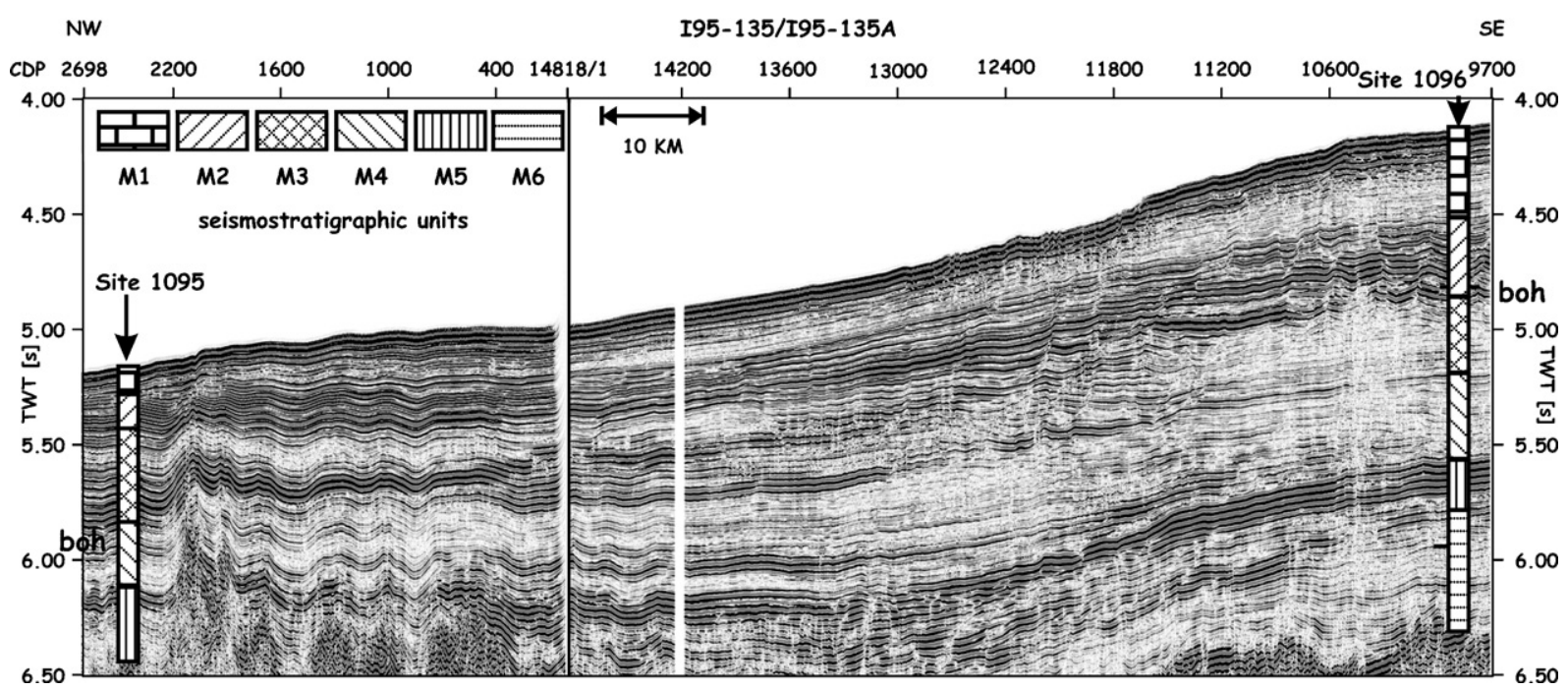

Fig. 2. Profile 195-135/135A showing location and the seismostratigraphic units defined by Rebesco et al. (1997) at the two ODP Leg 178 Sites 1095 and 1096 (Shipboard Scientific Party, 1999a,b). boh=base of hole, shows the maximum depth drilled at the ODP sites. For location, see Fig. 1.

compute sedimentation rates, I used the root mean square (rms) value of the unit's thickness and the revised age. The most obvious observation here is that the values published by Rebesco et al. (1997) are much higher than ours (Table 1). This is most certainly due to the fact that (a) Rebesco et al. (1997) studied sedimentation rates at a specific location at the gentle flank of Drift 7 on profile IT92-109, whereas I investigated the value for each whole sedimentary unit. This was done by using the results of ODP Leg 178 (Shipboard Scientific Party, 1999a,b; Volpi et al., 2002). I observe that sedimentation rates increase until unit M2 and show a slight decrease during unit M1. Accumulation rates still give a better idea on the amount deposited and hence were computed as well. To do this I used the rms-value of the unit's thickness and the revised age. The accumulation rates show highest values for unit M4 and a steady decrease for the younger units.

\section{Results}

To better define and describe the sedimentary environments, the seabed reflection and interfaces M1/

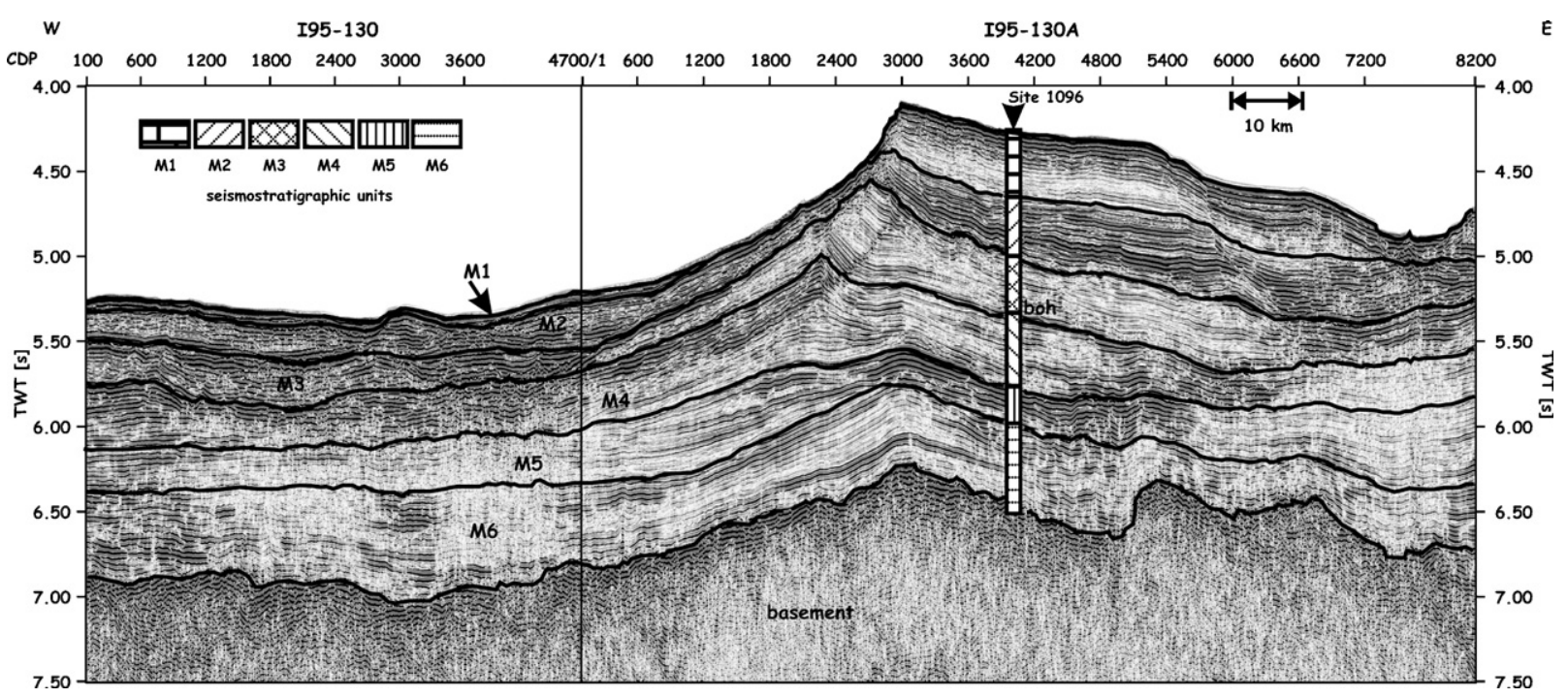

Fig. 3. Profile I-95-130/130A showing location and the seismostratigraphic units defined by Rebesco et al. (1997) at ODP Leg 178 Site 1096 (Shipboard Scientific Party, 1999a). boh=base of hole, shows the maximum depth drilled at the ODP site. For location see Fig. 1. 

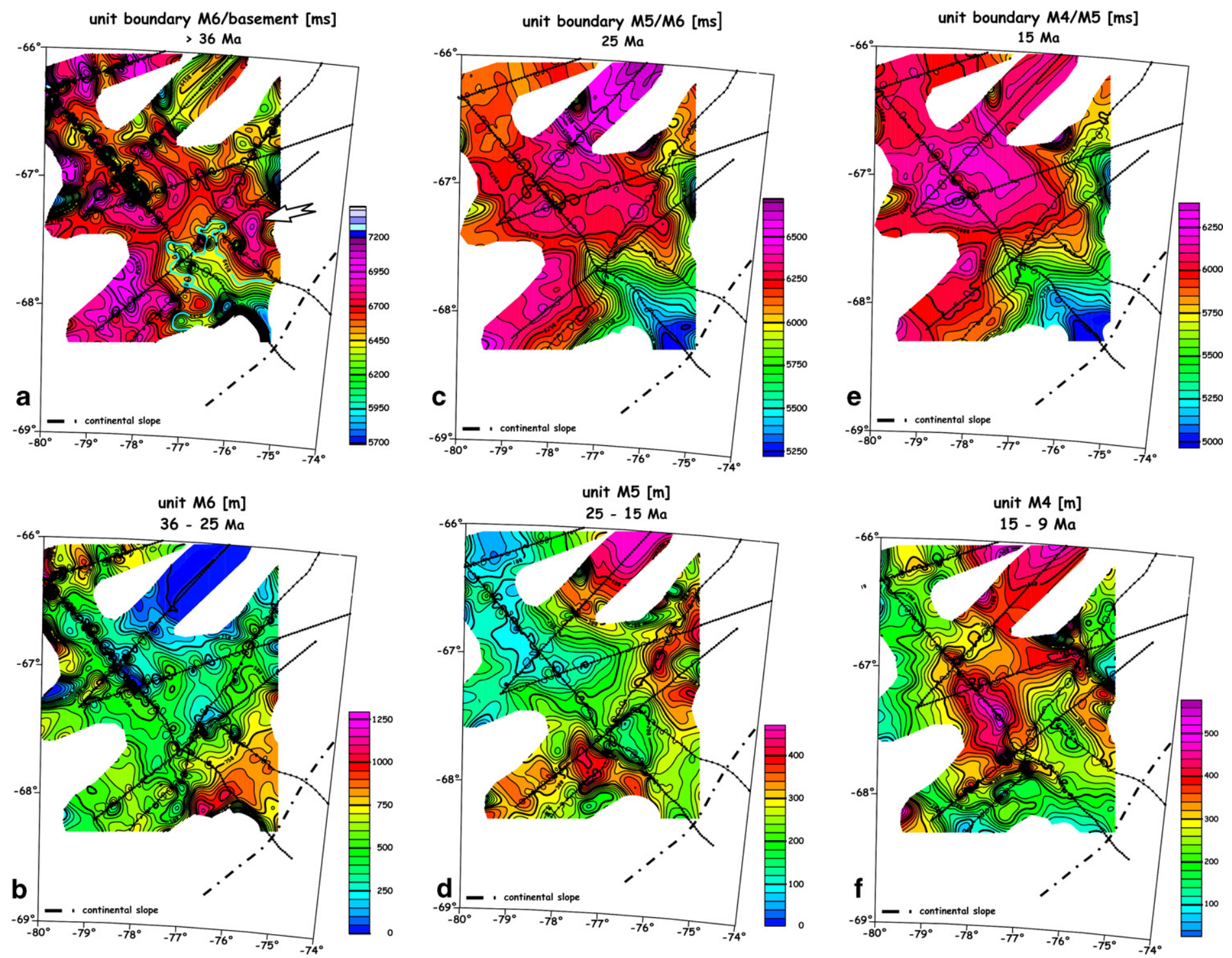

Fig. 4. Maps of reflector depth (interface M6/basement to M1/M2) and unit thickness (units M6 to M1) at Drift 7. Note the different depth and thickness ranges of the maps. The dot-dashed line shows the location of the slope. For discussion see text. 

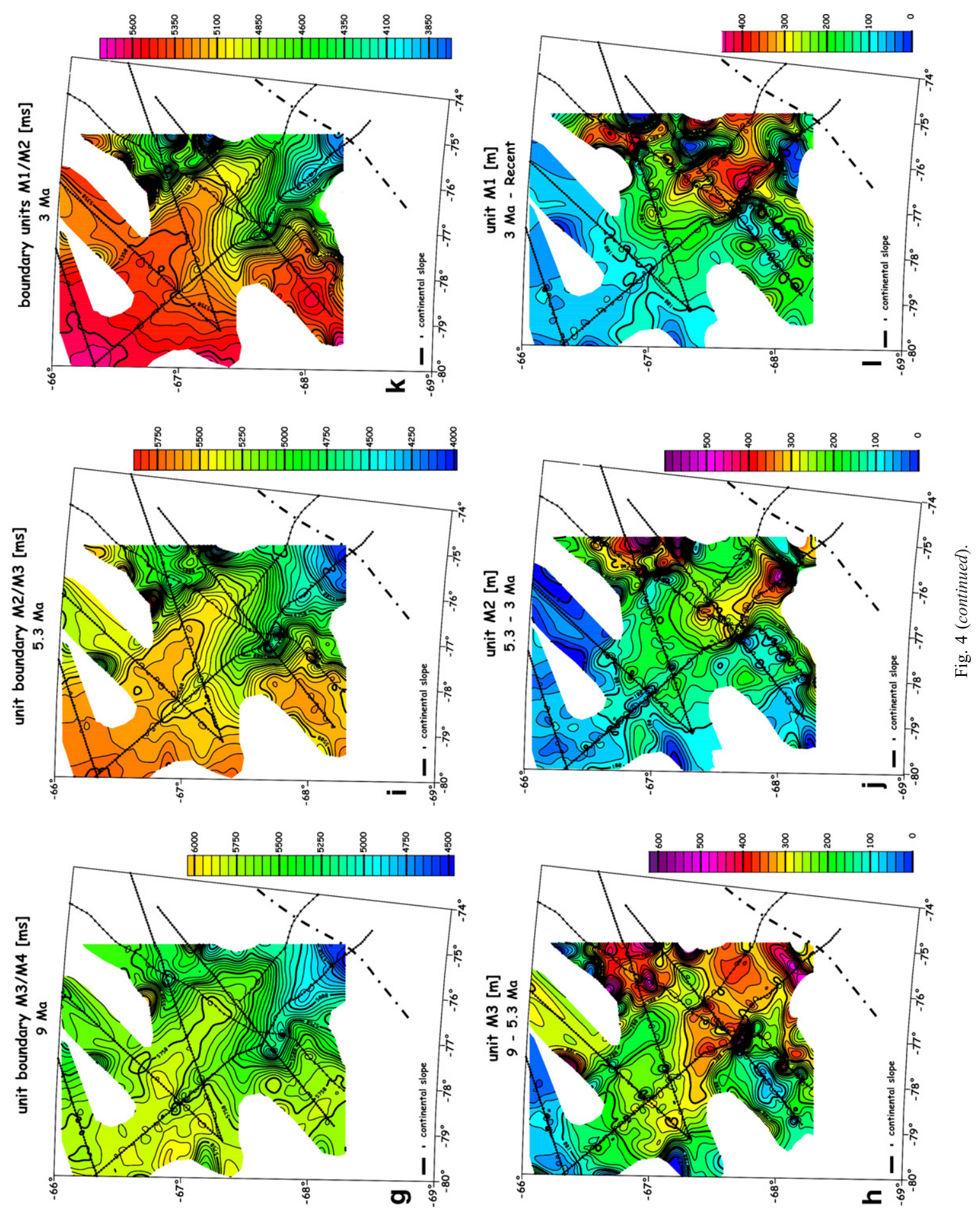
M2, M2/M3, M3/M4, M4/M5, M5/M6, and M6/basement were tracked, thicknesses of the different units computed, and maps of reflector depth and unit thickness compiled. Since reliable velocities were only at hand at the locations of ODP Leg 178 Sites 1095 and 1096 the maps of reflector depth are still in milliseconds two-way traveltime (TWT) and strictly do not represent depth. The term is just used for better clarity. The maps of unit thickness were converted from milliseconds TWT into meters thickness applying the second-order polynomial regressions describing the relationship between TWT (in $\mathrm{ms}$ ) and subbottom depth (in mbsf) at Sites 1095 and 1096 deduced by Volpi et al. (2002).

Reflector outlines and unit depocentres will be discussed. Both terms are defined as the root mean square (rms) value of the reflector depths and unit thicknesses, respectively. Their shape and location relative to the continental slope and the older outlines and depocentres are interpreted as indications for the major transport and depositional process. I interpret a depocentre oriented parallel to the continental slope to represent mainly along-slope transport, whereas a depocentre perpendicular to the slope indicates down-slope material transport. The direction of the along-slope transport is inferred from the location of the depocentre with respect to an older drift crest.

The maps shown in Fig. 4a-1 show high-frequency variations parallel to the seismic lines. Those features represent true values. They can be observed at crossings of seismic lines as well. Still, in my interpretation I concentrate on features larger than $20 \mathrm{~km}$.

Interface M6/basement appears as an elongate, ridgeshaped feature protruding from the continental slope (Fig. 4a). The depth isoline $6450 \mathrm{~ms}$ shows this basement ridge clearly (cyan line in Fig. 4a). Towards the NE, a trough can be observed before the surface rises again (grey arrow in Fig. 4a). This seabed elevation is probably the SW flank of Drift 6 . Towards the SW and NW the interface deepens. Unit M6 shows an up to 1100-m-thick depocentre close to the continental slope (Fig. 4b). The depocentre extends parallel to the slope with its thickest part in the SW. Towards the NW unit M6 thins again and reaches values between $300 \mathrm{~m}$ and $600 \mathrm{~m}$.

The interface between units M5 and M6 appears similar to interface M6/basement. The form of Drift 7 can already be identified, it is broader than interface M6/ basement but the structure still rests close to the continental slope (Fig. 4c). Towards the SW and NW the depth of the interface increases, whereas it rises again towards the NE where Drift 6 is located. The depocentre of unit M5 no longer rests parallel but rather perpendic- ular to the slope, and hence, parallel to the strike of the sediment drift. The depocentre has a maximum thickness of $420 \mathrm{~m}$ and extends farther seaward than unit M6's depocentre (Fig. 4d).

Interface M4/M5 shows the sediment drift to be broader (Fig. 4e). Its shape is more like a fan growing out of the continental slope with its tip towards the NW. There is no indication for a channel between Drift 6 and Drift 7, just a slight indention. Unit M4 shows a depocentre much farther seaward than unit M5. In contrast to unit M5, the depocentre of unit M4 lies seaward of the major outline of the interface M4/M5 (Fig. 4f). The thickness rises from about $200 \mathrm{~m}$ at the slope to $580 \mathrm{~m}$ in the depocentre. Towards Drift 6 in the NW unit M4 thins before again increasing in thickness. In the north unit M4 shows a 'finger' reaching out towards Drift 6.

As a consequence of higher accumulation rates in unit M4 (Table 1), the interface M3/M4 now extends farther into the ocean. No channel can be observed between Drift 7 and the continental slope (Fig. 4g). In contrast, the interface still appears to protrude from the slope. A depression begins its development in the NE towards Drift 6. The drift has not been built farther out with unit M3. Instead of one big depocentre I can now observe three smaller ones: one at the slope, and two other located on the northeastern part of the drift into the trough towards Drift 6 (Fig. 4h). The depocentres now show a steep flank in the SW and soft thinning towards the NE, i.e., they represent the present-day shape of Drift 7.

The outline of Drift 7 is fully developed with unit boundary M2/M3 (Fig. 4i). I observe a steep SW flank and a gentle NE flank. The channel towards Drift 6 is slightly better developed and deeper. Compared to unit M3, unit M2 shows a much smaller depocentre located closer to the continental slope. The depocentre is still located to the NE of the drift crest (Fig. 4j). The tip of the drift (formed by the interface M2/M3) is not covered by the depocentre of unit M2.

Drift 7 is extremely well defined in the interface M2/ M1. A small plateau can still be observed near the continental slope (Fig. 4k). The channel towards Drift 6 appears slightly less steep and a bit broader. Unit M1 shows a broader depocentre compared to unit M2, which is located slightly farther seaward (Fig. 41). It shows a thinning towards the continental slope but in places can still be identified.

\section{Discussion}

Rebesco et al. (1997) interpreted unit M6 as a mainly turbiditic sequence near the margin. They report that the unit thins away from the slope. My observations, a 
depocentre close and parallel to the slope, also point towards material derived from the continental shelf, which was moved down the slope. There, the sediment was deposited primarily close to the slope and SW of the crest of interface M6/basement. This indicates a process which involved less energy than a big mass movement event, thus resulting in a shorter transport distance. Here, I can follow the model of McGinnis et al. (1997) who interpreted an initial deposition after shelf erosion. Furthermore, the orientation of the depocentre argues for a secondary transport of the sediment, since the depocentre is not evenly distributed but much thicker in the SW. This cannot simply be an effect of the Coriolis force on the down-slope movement, because in that case I would expect even less sediment in the NW. Hence, I suggest a bottom current setting towards the SW. This current picked up the sediment and re-deposited it further downstream.

From the form and orientation of unit M5 (elongate, perpendicular to the slope) I infer that the sediment now was introduced into the system with more powerful sediment flows than before. It was transported farther out and mainly deposited on the SW side of the drift. I interpret this to represent re-deposition of sediment in a SW-setting bottom current. A plastered deposit due to a NE-directed bottom current as suggested by HernandezMolina et al. (2004) for this period can be ruled out because in that case the location of the depocentre would point to a very deep bottom current, which was unable to flow over the interface M5/M6. A NE-setting current would also be deflected northwestward by the drift (effect of topography, Pond and Pickard, 1983). But I see no evidence for this in the depocentre of unit M5. Thus, I infer a SW direction for the bottom current. Rebesco et al. (1997) interpreted unit M5 as a distal turbiditic succession. Even though the depocentre of unit M5 is farther away from the slope compared to unit M6, I prefer to avoid the term "distal" for this unit. In their depositional model, McGinnis et al. (1997) proposed mass movement via slumps, debris flows and turbidity currents as their second phase. My results are consistent, but moreover suggest re-deposition via a SW-setting bottom current.

The location of the depocentres of units M6 and M5 on the SW side (on the lee side) of the basement ridge indicates that here the basement topography obviously played a major role in the nucleation of the drift.

The big depocentre, which is located farther seaward than the older depocentres, suggests that most sediment was deposited via more powerful mass movement during the period of unit M4 (15-9.5 Ma). This increased mass movement could have been a result of an ice advance in mid-/late Miocene times, which coincides with the increase in ice volume as documented via the oxygen isotope record for the period following $12 \mathrm{Ma}$ (Zachos et al., 2001). This led to the longer transport path compared to the older units. Furthermore, the bottom current intensified and episodically eroded at the base of the slope. This led to a thinner sequence near the slope with a thicker depocentre farther out.

Erosion down to unit M2 can be seen between CDPs 3300 and 6000 on line IT95-135 (Fig. 5). It has been

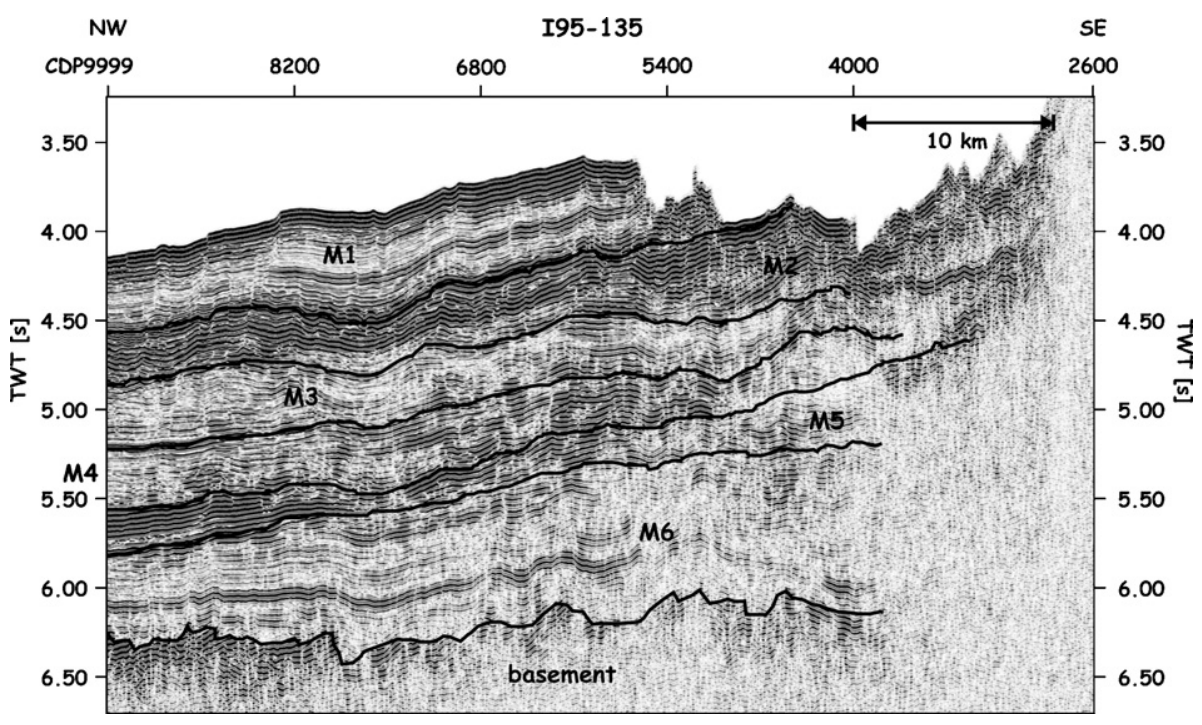

Fig. 5. Profile I95-135 showing an erosional feature at the base of the slope. This erosional feature most probably is the result of the southwest setting bottom current observed today. For location, see Fig. 1. 
proposed by Rebesco et al. (2002) that turbidity currents here erode and generate channels. Interface M4/M5 shows a local highstand at CDP 5400 against which unit M4 thins. Interface M3/M4 here appears rough with indications for erosional truncation. This may indicate an enhanced sediment input in unit M4 with erosion near the slope due to a SW-setting current. Another possibility would be younger erosion, which cut into the older layers of unit M4.

Rebesco et al. (1997) considered unit M4 to be part of the drift growth stage with variations in thickness as a result of increasing bottom current activity and larger glacial input. In Early Miocene times, gaps opened in the South Scotia Sea (Livermore et al., 2004). This may have favoured the initiation of a SW-oriented bottom-water flow along the margin of the northern and western Antarctic Peninsula. From the structure of a buried drift slightly farther NE, Hernandez-Molina et al. (2004) concluded that a major change in palaeoceanographic conditions occurred from early Miocene $(>15 \mathrm{Ma})$ to middle Miocene $(<15 \mathrm{Ma})$. Since they observed a NEsetting current in the early Miocene they suggest a change to southwestward bottom-current flow as a representative of the initial incursion of Lower Circumpolar Deep Water (LCDW) from the Weddell Sea into this area. As an alternative, they discuss a northward shift in ACC fronts, allowing the LCDW from the Weddell Sea to spread further across the rise. This northward shift in ACC fronts may be the result of an expanded ice sheet as well and would hence support my interpretation.

Rebesco et al. (1997) interpreted unit M3 as the main phase of drift development. They observe an asymmetric deposition with thicker sequences in the SW. My observations (no further build-out of the drift, three smaller depocentres instead of a big one) rather point to a continued build-up of Drift 7 with the major phase occurring during unit M4 times.

For unit M3 I interpret less vigorous sediment input compared to unit M4, which was mainly down-slope because the depocentres are NE of the drift crest. I suggest a shorter transport path, which may indicate a slight retreat of the ice as well as a relocation of the bottom current towards the North. I hence observe erosion in the North instead of near the slope. Accumulation rates decreased compared to unit M4 (Table 1), which also argues for less sediment input.

From the still smaller depocentre of unit M2 I infer a further decrease in force for the sediment input from the shelf leading to deposition close to the source. The material then was picked up by a weaker SW-setting current (cf. Hernandez-Molina et al., 2004) and eroded from the steep SW flank of the drift. This may explain the smaller depocentre with the higher sedimentation rates compared to unit M3 (Table 1). No further build-out of the drift can be observed. While depocentres of Drifts 6 and 7 have still been connected in unit M3 times, they now are separated by a strong thinning in unit M2 (Fig. 4j).

Rebesco et al. (1997) reported a uniform thickness for unit M2 on the gentler side and its near absence on the steeper side. They correlated unit M2 with the beginning of the drift maintenance stage leading to preservation and enhancement of the elevation of Drift 7 (Rebesco et al., 1997, 2002). My observation also suggests that the drift was no longer built out. Accumulation rates further decreased for unit M2.

The form of unit M1 depocentre (Fig. 41) indicates an increase in sediment input compared to unit M2, probably as the result of the strong glacial phases in the Quaternary. I observe a strong decrease in thickness towards Drift 6, which indicates erosion. This is observed in the seismic lines (see, e.g., Fig. 10 of Rebesco et al., 2002). The general structure shows a steep SW flank and a gentle NE flank. Unit M1's depocentre is also located NE of the crest visible in interface M1/M2. I consider post-depositional erosion as the reason for this.

\section{Depositional model}

My interpretation of sedimentary structures and maps of reflector depth and unit thickness led to the construction of a self-consistent model for the deposition at Drift 7 since the Oligocene. Fig. 6 shows the different stages of the scenario from unit M6 (3625 Ma, Fig. 6a) to unit M1 (3 Ma-present, Fig. 6f). The shaded areas show the main outline of the unit's base horizon (rms values, see Results) while the hatched areas show the depocentres (rms values, see Results) of the unit. The bold arrows represent the material input from the shelf (turbiditic), and the open arrows mark the material transported by bottom currents (contouritic).

Additionally, an attempt was made to extend this model into a model of the oceanographic development at this part of the Antarctic Peninsula to see it in a broader perspective. Fig. 7 shows the location of the southern front of a Proto-ACC (dashed line) and the grounded ice sheet (dotted line and grey area).

For the period 36-25 Ma the continental shelf appeared to be the main sediment source. The depocentre of unit M6 is located close to and parallel to the continental slope (Figs. 4b and 6a). The material then might have been picked up by a weak SW-setting bottom current. During the period 25-15 Ma, this becomes more obvious. The depocentre of unit M5, which is elongate 
and located perpendicular to the continental slope indicating down-slope transport, rests on the SW side of interface M5/M6, but still close to the continental slope (Figs. $4 \mathrm{~d}$ and $6 \mathrm{~b}$ ). Material input from the shelf was picked up by a stronger SW-setting bottom current and deposited on the lee side of the basement ridge protruding from the shelf.

The period from 36 to $15 \mathrm{Ma}$, hence, gives little indications for a major down-slope transport (turbiditic). Sediment input from the continental shelf was low and the material was moved towards the SW. The major transport appeared to be along-slope (contouritic). From the investigation of a buried drift Hernandez-Molina et al. (2004) inferred a NE-setting Proto-CDW before $15 \mathrm{Ma}$ (dashed arrows in Fig. 6a and b). I see no evidence for this. Such a current would be deflected towards the
NW when encountering the elevation of the basement ridge and interface M5/M6 (topographic effect, Pond and Pickard, 1983). Instead of depositing unit M5 SW of the basement ridge, i.e., in front of the ridge from the current's perspective, a NE-setting current would take the sediment load to the seaward tip and the NE of the drift. This cannot be observed. A solution may be the Migration and Coexistence Hypothesis of HernandezMolina et al. (2006). They propose that during most of the Miocene, the influence of Weddell Sea Deep Water (WSDW) along the South Scotia Ridge, and Lower Circumpolar Deep Water (LCDW) from the Weddell Sea along the Pacific margin of the Antarctic Peninsula was less extensive than since the late Miocene, but still active. As a consequence, it was restricted to the upper rise. Hence, CDW within the ACC could circulate closer
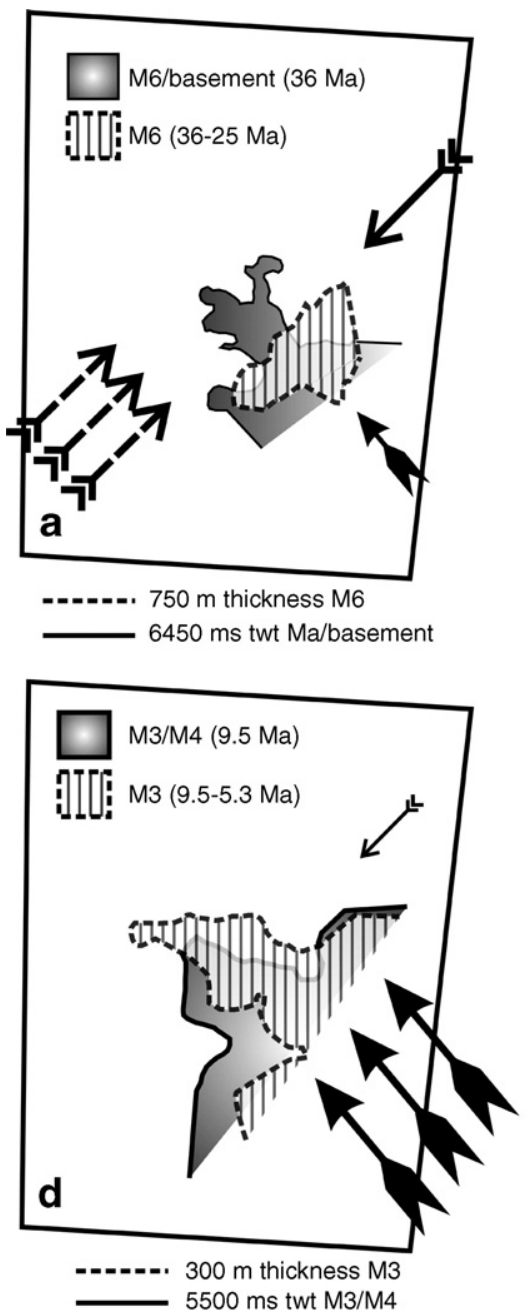
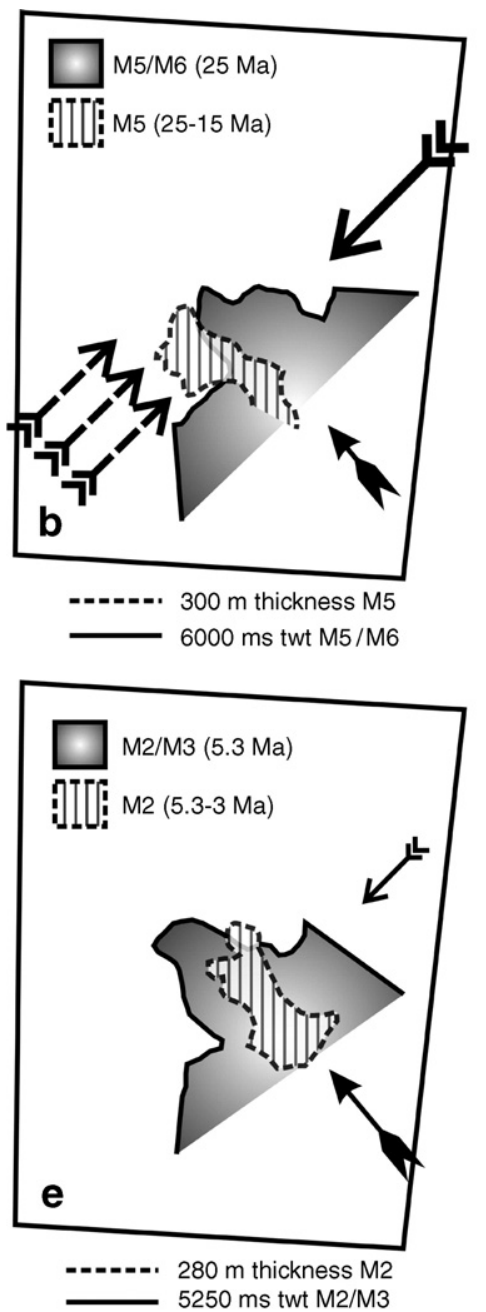
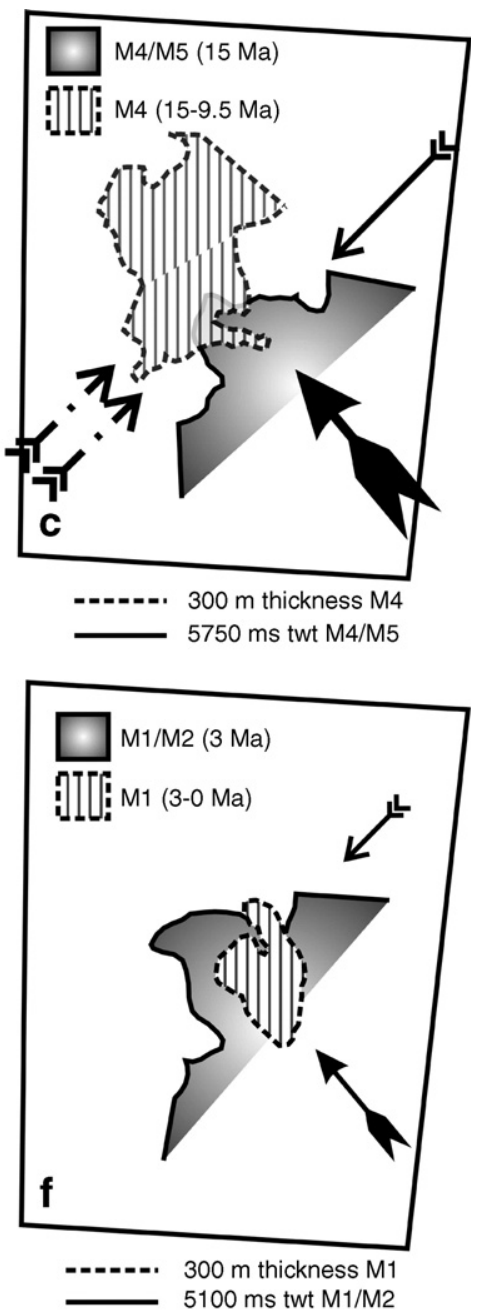

Fig. 6. Depositional model for Drift 7. Major outline of each unit's base (grey area) and depocentre (hatched area) are displayed. The open arrow shows the along-slope transport, while the closed arrow shows the down-slope transport. The thickness and length of the arrows indicate the importance of the process. Dashed and dot-dashed arrows show the NE setting current proposed by Hernandez-Molina et al. (2004, 2006). 

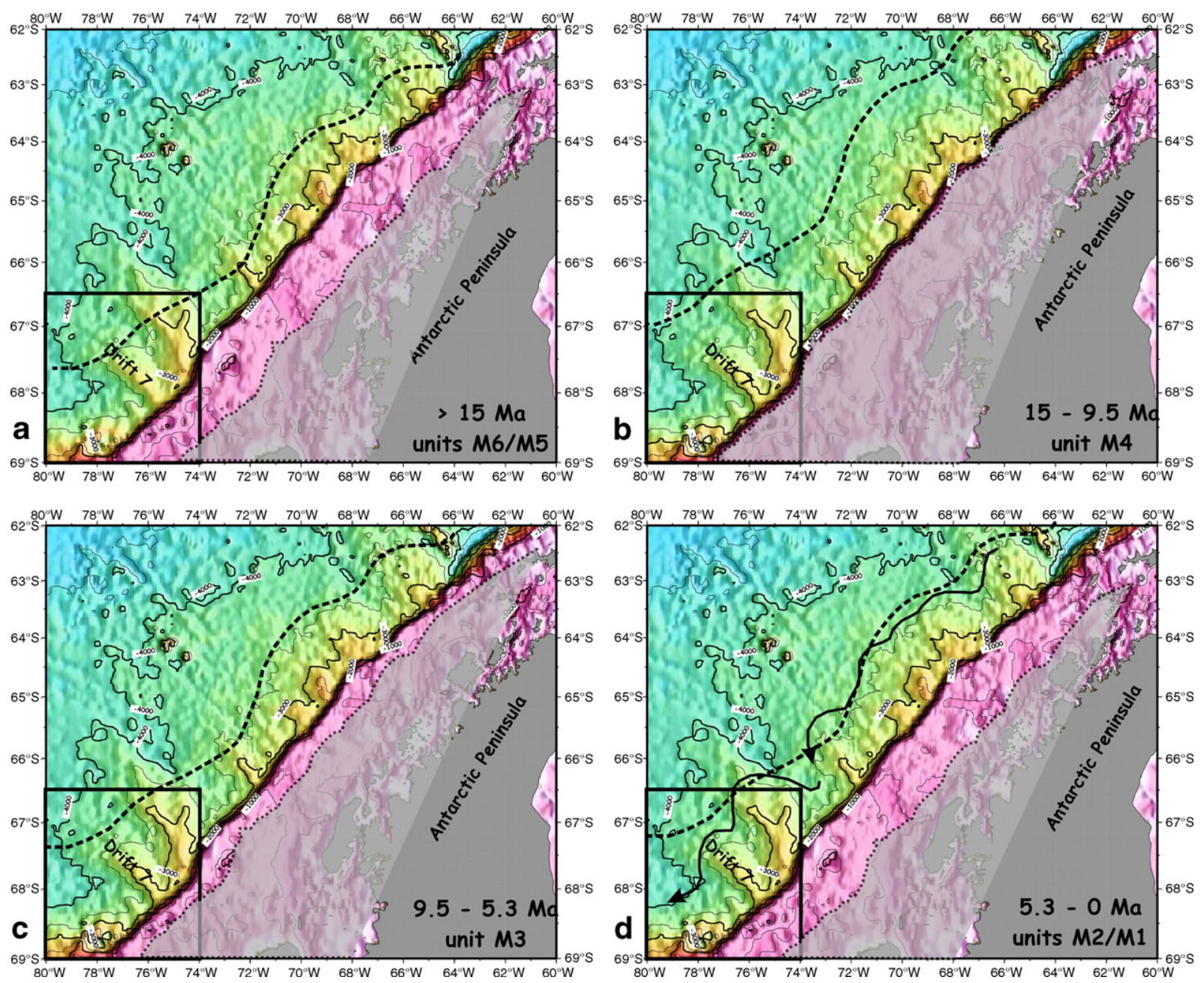

Fig. 7. Oceanographic model inferred for four periods. The grey area refers to the extent of grounded ice, the dashed line shows the location of the southern ACC front, and the small arrows show the southwest setting bottom current (d).

to the margin. Later, a more intense bottom-water circulation during the late Miocene could have been associated with increased LCDW outflow from the Weddell Sea . Thus, LCDW extended over the central rise and displaced CDW further to the north.

The period 15-9.5 Ma experienced a distinct change in deposition. Sediment input from the continental slope strongly increased leading to a big depocentre seaward of the drift (Figs. 4f and 6c). The down-slope transport became the major component, while the along-slope component weakened. This may be a result of the repeated advance of grounded ice streams to the shelf break, which introduced more material into the system (Fig. 7b). The Proto-ACC was now located farther north. The SW-setting bottom current may have persisted leading to further erosion near the slope, but its intensity was probably weakened.
The period 9.5-5.3 Ma advance of the grounded ice to the shelf break decreased resulting in less down-slope sediment input. The depocentre of unit M3 was located closer to the slope than unit M4's depocentre (Figs. 4f, $4 \mathrm{~h} 6 \mathrm{c}$ and d) and accumulation rates show less sediment input (Table 1). Sykes et al. (1998) observed a reactivation of $\mathrm{AABW}$, which support a southward move of the Proto-ACC as I suggested (Fig. 7c). Still, I have no indications for a SW-setting bottom current on Drift 7 as vigorous as during period $25-15 \mathrm{Ma}$. This may indicate that the Proto-ACC was located still farther north than during the period 25-15 Ma.

Hernandez-Molina et al. (2006) proposed a palaeoceanographic change from a NE-setting Proto-CDW (dot-dashed arrow in Fig. 6c) to the presently observed SW-flowing branch of LCDW originating in the Weddell Sea for the period 15-5 Ma. Although my 
investigations do not show evidence for the NE-setting current prior to $15 \mathrm{Ma}$, traces of a bottom current setting southwestwards can be observed for the periods 159.5 Ma (unit M4) and 9-5.3 Ma (unit M3).

The input of sediment since $5.3 \mathrm{Ma}$ has further decreased. The depocentres of units M2 and M1 are much smaller, but located right on top of Drift 7 (Figs. 4j, 1, 6e and $\mathrm{f}$ ). This indicates a shift of the ACC to the north and the pick-up of material in the SW-setting LCDW (Fig. 7d).

\section{Conclusions}

Maps of reflector depth and unit thickness of Drift 7 were interpreted with respect to depositional patterns. Those depositional patterns were considered to give information on the sediment transport processes (alongslope versus down-slope) active at this part of the continental margin of the Antarctic Peninsula during the Neogene. I also hypothesise on oceanographic and climatic conditions.

I compiled a self-consistent depositional model, which showed that the along-slope transport was the major component during the period 25-15 Ma. Material contributed from the continental shelf was picked up by a SW-setting bottom current and deposited on the lee side of a basement ridge protruding from the shelf. Thus, the formation of the drift benefited from the basement topography.

During the period 15-9.5 Ma, down-slope transport became the major process. I observe a strong increase in sediment input from the shelf, which is no longer deflected to the SW. This was probably the result of the growth of the Antarctic Peninsula ice cap.

A decrease in sediment input during the period 9.55.3 Ma indicates a retreat of the ice. Nevertheless, indications for an increased along-slope transport cannot be found. This has changed since 5.3 Ma. Even though sediment input further decreased, the material was again picked up by a weak SW-setting bottom current.

\section{Acknowledgements}

I thank C.-D. Hillenbrand for tracking the seismic horizons and collaborating on the age model, and $\mathrm{M}$. Rebesco for permitting to use the Italian seismic data on Drift 7. Additionally, the discussion with both helped my work enormously, even though we could not derive a common hypothesis to write this publication together. Furthermore, I am grateful for the comments of David Piper, Peter Harris and an anonymous reviewer. This is Alfred-Wegener-Institut Contribution No. awi-n 16023. This research used data provided by the Ocean Drilling
Program (ODP). The ODP is sponsored by the U.S. National Science Foundation (NSF) and participating countries under management of Joint Oceanographic Institutions (JOI), Inc. The work was funded by the Deutsche Forschungsgemeinschaft under Contract No. Ue 49/5.

\section{References}

Acton, G.D., Guyodo, Y., Brachfeld, S.A., 2002. Magnetostratigraphy of sediment drifts on the continental rise of West Antarctica (ODP Leg 178, Sites 1095, 1096, and 1101). In Barker, P.F., Camerlenghi, A., Acton, G.D., A.T.S. Ramsay, (Eds.), Proc.ODP, Sci. Results, 178, 1-61 [CD-ROM]. Available from: Ocean Drilling Program, Texas A\&M University, College Station TX 77845-9547, USA.

Barker, P.F., Camerlenghi, A., Acton, G.D., et al., 1999. Antarctic glacial history and sea-level change. Initial Report of the Ocean Drilling Program, Leg 178. Proceedings ODP Init. Rep., vol. 178, pp. 1-60.

Barker, P.F., Camerlenghi, A., Acton G.D., Ramsay, A.T.S. et al., 2002. Proc. ODP, Sci. Results, 178, 1-40 (Online). Available from World Wide Web: $<$ http://www-odp.tamu.edu/publications/178_SR $>$.

Camerlenghi, A., Crise, A., Pudsey, C.J., Accerboni, E., Laterza, R., Rebesco, M., 1997. Ten-month observation of the bottom current regime across a sediment drift of the Pacific margin of the Antarctic Peninsula. Antarct. Sci. 9, 426-433.

Faugères, J.-C., Stow, D.A.V., 1993. Bottom-current-controlled sedimentation: a synthesis of the contourite problem. Sediment. Geol. 82, 287-297.

Faugères, J.-C., Stow, D.A.V., Imbert, P., Viana, A., 1999. Seismic features diagnostic of contourite drifts. Mar. Geol. 162, 1-38.

Giorgetti, A., Crise, A., Lazerna, R., Perini, L., Rebesco, M., Camerlenghi, A., 2003. Water masses and bottom boundary layer dynamics above a sediment drift of the Antarctic Peninsula Pacific Margin. Antarct. Sci. 15, 537-546.

Harris, P.T., Brancolini, G., Armand, L., Busetti, M., Beaman, R.J., Giorgetti, G., Presti, M., Trincardi, F., 2001. Continental shelf drift deposits indicates non-steady state Antarctic bottom water production in the Holocene. Mar. Geol. 179, 1-8.

Hernandez-Molina, F.J., Larter, R.D., Rebesco, M., Maldonado, A., 2004. Miocene changes in bottom current regime recorded in continental rise sediments on the Pacific Margin of the Antarctic Peninsula. Geophys. Res. Lett. 31, L22606. doi:10.1029/1004GL020298.

Hernandez-Molina, F.J., Larter, R.D., Rebesco, M., Maldonado, A., 2006. Miocene reversal of bottom current flow along the Pacific Margin of the Antarctic Peninsula: stratigraphic evidence from a contouritic sedimentary tail. Mar. Geol. 228, 93-116.

Hofmann, E.E., Klinck, J.M., Lascara, C.M., Smith, D.A., 1996. Water mass distribution and circulation west of the Antarctic Peninsula and including Bransfield Strait. In: Ross, R.M., Hofmann, E.E., Quetin, L.B. (Eds.), Foundations for Ecological Research West of the Antarctic Peninsula. Antarctic Research Series, vol. 70. AGU, Washington, DC, pp. 61-80.

Iwai, M., Acton, G.D., Lazarus, D., Osterman, L.E., Williams, T., 2002. Magnetobiochronologic synthesis of ODP Leg 178 rise sediments from the Pacific sector of the Southern Ocean: Sites 1095, 1096, and 1101. In Barker, P.F., Camerlenghi, A., Acton, G. D., Ramsay, A.T.S. (Eds.), Proc.ODP, Sci. Results, 178, 1-40 [CD-ROM]. Available from: Ocean Drilling Program, Texas A and M University, College Station TX 77845-9547, USA.

Larter, R.D., Rebesco, M., Vanneste, L.E., Gambôa, L.A.P., Barker, P.F., 1997. Cenozoic tectonic, sedimentary and glacial history of the 
continental shelf west of Graham Land, Antarctic Peninsula. In: Barker, P.F., Cooper, A.K. (Eds.), Geology and Seismic Stratigraphy of the Antarctic Margin, 2. Antarctic Research Series, vol. 71, pp. 29-49. AGU.

Latimer, J.C., Filippelli, G.M., 2002. Eocene to Miocene terrigenous inputs and export production: geochemical evidence from ODP Leg 177, Site 1090. Palaeogr. Palaeoclimatol. Palaeoecol. 182, $151-164$

Livermore, R., Eagles, G., Morris, P., Maldonado, A., 2004. Shakleton fracture zone: no barrier to early circumpolar ocean circulation. Geology 32, 797-800.

Lucchi, R.G., Rebesco, M., Camerlenghi, A., Busetti, M., Tomadin, L., Villa, G., Persico, D., Morigi, C., Bonci, M.C., Giorgetti, G., 2002. Mid-late Pleistocene glacimarine sedimentary processes of a high-latitude, deep-sea sediment drift (Antarctic Peninsula Pacific margin). Mar. Geol. 189, 343-370.

McGinnis, J.P., Hayes, D.E., 1995. The roles of down-slope and alongslope depositional processes: southern Antarctic Peninsula continental rise. In: Cooper, A.K., Barker, P.F., Brancolini, G. (Eds.), Geology and Seismic Stratigraphy of the Antarcitc Margin. Antarctic Research Series, vol. 68, pp. 141-156.

McGinnis, J.P., Hayes, D.E., Driscoll, N.W., 1997. Sedimentary processes across the continental rise of the southern Antarctic Peninsula. Mar. Geol. 141, 91-109.

Orsi, A.H., Whitworth III, T., Nowlin Jr., T., 1995. On the meridional extent and fronts of the Antarctic Circumpolar Current. Deep-Sea Res. I 42, 641-673.

Patterson, S.L., Whitworth III, T., 1990. Physical Oceanography. In: Glasby, G.P. (Ed.), Antarctic Sector of the Pacific. Elsevier Oceanographic Series, vol. 51. Elsevier, Amsterdam, pp. 55-93.

Pfuhl, H.A., McCave, I.N., 2005. Evidence for late Oligocene establishment of the Antarctic Circumpolar Current. Earth Planet. Sci. Lett. 235, 715-728.

Pickering, K., Hiscott, R., Hein, F., 1989. Deep marine environments: clastic sedimentation and tectonics. Chapter 9. Contourite Drifts. Unwin Hyman Ltd, London, pp. 218-245.

Pond, S., Pickard, G.L., 1983. Introductory Dynamical Oceanography. Pergamon Press. 329 pp.

Rebesco, M., Larter, R.D., Camerlenghi, A., Barker, P.F., 1996. Giant sediment drifts on the continental rise west of the Antarctic Peninsula. Geo-Mar. Lett. 16, 65-75.

Rebesco, M., Larter, R.D., Barker, P.F., Camerlenghi, A., Vanneste, L.E., 1997. The history of sedimentation on the continental rise west of the Antarctic Peninsula. In: Barker, P.F., Cooper, A.K. (Eds.), Geology and seismic stratigraphy of the Antarctic margin, 2. Antarctic Research Series, vol. 71, pp. 29-49. AGU.

Rebesco, M., Camerlenghi, A., Zanolla, C., 1998. Bathymetry and morphogenesis of the continental margin west of the Antarctic Peninsula. Terra Antartica 5 (4), 715-725.

Rebesco, M., Pudsey, C.J., Canals, M., Camerlenghi, A., Barker, P.F., Estrada, F., Lucchi, R., Giorgetti, A., 2002. Sediment drift and deep-sea channel systems, Antarctic Peninsula Pacific Margin. In: Stow, D.A.V., Faugeres, J.-C., Howe, J., Pudsey, Viana, A. (Eds.), Deep-Water Contourite Systems: Modern Drifts and Ancient Series, Seismic and Sedimentary Characteristics. Geological Society of London Memoirs, vol. 22, pp. 353-371.

Rebesco, M., Camerlenghi, A., Volpi, V., Neagu., C., Accettella, D., Lindbergh, B., Cova, A., Zgur, F., the MAGICO party, in press. Interaction of processes and importance of contourites: insights from the detailed morphology of sediment drift 7, Antarctica. In: Viana, A., Rebesco M. (Eds.), Economic and Paleoceanographic Importance of Contourites. Geological Society of London, Spec. Pub.
Shanmugam, G., 2000. 50 years of the turbidite paradigm (1950s1990s): deep-water processes and facies models - a critical perspective. Mar. Pet. Geol. 17, 285-342.

Shipboard Scientific Party, 1999a. Site 1095. In: Barker, P.F., Camerlenghi, A., Acton, G.D., et al. (Eds.), Proceedings of the Ocean Drilling Program. Initial Reports, vol. 178, pp. 1-173. CD-ROM.

Shipboard Scientific Party, 1999b. Site 1096. In: Barker, P.F., Camerlenghi, A., Acton, G.D., et al. (Eds.), Proceedings of the Ocean Drilling Program. Initial Reports, vol. 178, pp. 1-144. CD-ROM.

Shipboard Scientific Party, 1999c. Site 1101. In: Barker, P.F., Camerlenghi, A., Acton, G.D., et al. (Eds.), Proceedings of the Ocean Drilling Program. Initial Reports, vol. 178, pp. 1-83. CD-ROM.

Smith, W.H.F., Sandwell, D.T., 1997. Global seafloor topography from satellite altimetry and ship depth sounding. Science 277, 1956-1962.

Smith, D.A., Hofmann, E.E., Klinck, J.M., Lascara, C.M., 1999. Hydrography and circulation of the West Antarctic Peninsula continental shelf. Deep-Sea Res. I 46, 925-949.

Stow, D.A.V., Faugères, J.-C., Viana, A., Gonthier, E., 1998. Fossil contourites: a critical review. Sediment. Geol. 115, 3-31.

Stow, D.A.V., Faugères, J.-C., Howe, J.A., Pudsey, C.J., Viana, A.R., 2002. Bottom currents, contourites and deep-sea sediment drifts: current state of the art. In: Stow, D.A.V., Pudsey, C.J., Howe, J.A., Faugères, J.-C., Viana, A.R. (Eds.), Deep-Water Contourite Systems: Modern Drifts and Ancient Series, Seismic and Sedimentary Characteristics. Geological Society of London, Memoirs, vol. 22, pp. 7-20.

Stroeven, A.P., Burckle, L.H., Kleman, J., Prentice, M.L., 1998. Atmospheric transport of diatoms in the Antarctic Sirius Group: Pliocene Deep Freeze. GSA Today 8/4, 1-5.

Sykes, T.J.S., Ramsay, A.T.S., Kidd, R.B., 1998. Southern hemisphere Miocene bottom-water circulation: a palaeobathymetric analysis. In: Cramp, A., MacLeod, C.J., Jones, E.J.E. (Eds.), Geological Evolution of Ocean Basins: Results from the Ocean Drilling Program. Geological Society of London, Special Publication, vol. 131 , pp. $43-54$.

Tucholke, B.E., Hollister, C.D., Weaver, F.M., Vennum, W.R., 1976. Continental rise and abyssal plain sedimentation in the Southeast Pacific Basin—Leg 35 Deep Sea Drilling Project. In: Hollister, C.D., et al. (Ed.), Initial Reports of the Deep Sea Drilling Project, vol. 35. US Government Printing Office, Washington, DC, pp. 359-400.

Viana, A.R., Faugères, J.-C., Stow, D.A.V., 1998. Bottom-currentcontrolled sand deposits-a review of modern shallow- to deepwater environments. Sediment. Geol. 115, 53-80.

Volpi, V., Camerlenghi, A., Moerz, T., Corubolo, P., Rebesco, M., Tinivela, U., 2002. Data report: physical properties relevant to seismic stratigraphic studies, continental rise Sites 1095, 1096 and 1101, ODP Leg 178, Antarctic Peninsula. In Barker, P.F., Camerlenghi, A., Acton, G.D., Ramsay, A.T.S. (Eds.), Proc.ODP, Sci. Results, 178, 1-36 [CD-ROM]. Available from: Ocean Drilling Program, Texas A and M University, College Station TX 77845-9547, USA.

Whitworth III, T., Orsi, A.H., Kim, S.-J., Nowlin Jr., W.D., Locarini, R.A., 1998. Water masses and mixing near the Antarctic Slope Front. In: Jacobs, S., Weiss, R. (Eds.), Ocean, Ice and Atmosphere: Interactons at the Antarctic Continental Margin. Antarctic Research Series, vol. 75. AGU, Washington, DC, pp. 1-27.

Zachos, J., Pagani, M., Sloan, L., Thomas, E., Billups, K., 2001. Trends, rhythym, and abberations in global climate $65 \mathrm{Ma}$ to present. Science 292, 687-693. 